\title{
VIZUELNO PREDSTAVLJANJE GLAVNIH AKTERA SIROMAŠTVA U SRBIJI: SEMIOTIČKA ANALIZA TELEVIZIJSKE SLIKE I FOTOGRAFIJE U MEDIJSKIM TEKSTOVIMA ${ }^{1}$
}

U radu se analizira vizuelno predstavljanje glavnih aktera siromaštva u srpskim medijima. Vizuelno predstavljanje nije samo mehaničko oslikavanje stvarnosti, i zbog toga nesumnjivo ima veoma važnu ulogu u oblikovanju značenja tema i događajma u javnosti. Zato je cilj istraživanja u radu bio da se utvrdi na koji način se vizuelnim kodom prenose poruke o siromaštvu i socijalno isključenim grupama $u$ analiziranim televizijskim vestima $i$ fotografijama koje su ilustrovale posmatrane tekstove. Metodama analize sadržaja, kritičkih studija diskursa i semiotičkog pristupa posmatran je uzorak od 410 tekstova o siromaštvu koji su prikupljeni u periodu od 14. do 28. oktobra 2010. i 2011 godine. Analiza strukture diskursa pokazuje da je vizuelno predstavljanje glavnih aktera siromaštva pojednostavljeno, stereotipno i daleko od prikazivanja celokupnog konteksta. Svedeno je na male delove slika, koji nemaju tu snagu da dočaraju na pravi način ozbiljnu problematiku siromaštva i sa kojim se masovna publike teško identifikuje.

Ključne reči: siromaštvo, vizuelno predstavljanje, televizijska slika, fotografija, analiza diskursa, socijalna semiotioka

Vizuelno predstavljanje pojava, događaja i ličnosti u medijskim tekstovima nije samo mehaničko oslikavanje stvarnosti i zbog toga se ističe njegov uticaj na vrednosnu orijentaciju čitalaca, odnosno gledalaca. Samo predstavljanje, kako zapaža Mek Kvin (2000: 179), jeste slika, sličnost sa nečim ili reprodukovanje nečega što postoji u „realnom svetu“, ali za razliku od pisanog teksta koji je očigledan

1 Rad je nastao na osnovu rezultata naučnoistraživačkog projekta Medijski diskurs o siromaštvu $i$ socijalnoj isključenosti, koji je sproveo Odsek za medijske studije Filozofskog fakulteta u Novom Sadu. Projekat je realizovan u okviru Regionalnog programa podrške istraživanjima u oblasti društvenih istraživanja na Zapadnom Balkanu (RRPP), koji vodi Univerzitet u Friburgu, uz finansijsku podršku Švajcarske agencije za razvoj i saradnju (SDC). Mišljenja izneta u ovom izveštaju su mišljenja autora i ne predstavljaju nužno mišljenja SDC niti Univerziteta u Friburgu. 
posredan prikaz, vizuelne predstave deluju dosta ubedljivije. Naime sadržaj nekog događaja ponovo predstavljen u vidu znakova na stranici, tj. ,rečima“ teško se može pomešati sa onim stvarnim, dok kod medija kao što su televizija, film, itd. to ponovno predstavljanje (re-prezentacija) mnogo više podseća na naše lično doživljavanje stvarnosti.,Na taj način televizija ponovo predstavlja stvarni svet, $i$ to na površinskom nivou, slično onome kako mi našim čulima vida i sluha „tumačimo“ doživljaj (2000: 180). Svaka predstava koju gledamo, čak i ona koju primamo sopstvenim čulima, sadrži samo jedan delić onoga što je moglo da se prikaže, te se stoga svodi samo na „selektivnu apstrakciju“. Zato, Mek Kvin zaključuje da je svako predstavljanje selektivno, ograničeno ili kadrirano, „univokalno“ ( $\mathrm{tj}$. samo sa jedne pozicije). Hol medijski rad na predstavljanju stvarnosti vidi kao „aktivni proces selekcije, prikazivanja, strukturisanja i oblikovanja“ čiji cilj nije samo „preneti postojeće značenje nego i aktivno raditi na tome da stvari dobiju značenje“ (Hall 1982: 64).

Definisana kao udvojena stvarnost, televizijska slika zapravo predstavlja novu stvarnost svojstvenu samo televiziji. „To je stvarnost prezentovana sistemom audiovizuelnih simbola i kompleksom uzajamno determinisanih kodova i potkodova, koja predstavlja simulaciju realnih događaja i pojava kroz vremensku i prostornu iluziju.“" (Bodrijar 1991 :10)

Audio-vizuelna komunikacija na TV mediju odvija se na logičkointelektualnom i emocionalno-afektivnom planu, posredovanjem semantičkih, odnosno estetičkih poruka. Razumevanje estetske poruke, prema Umbertu Eku, zasniva se na dijalektici između prihvatanja i odbacivanja kodova i potkodova eminenta s jedne, i uvođenja i odbacivanja ličnih kodova i potkodova, s druge strane: „To je dijalektika između interpretativne doslednosti i slobode, gde primalac, s jedne strane, pokušava da odgovori na poziv dvosmislene poruke i da nejasnu formu ispuni sopstvenim kodovima; s druge strane, kontekstualne relacije omogućuju mu da poruku sagleda onako kako je ona sačinjena, ostajući veran njegovom autoru i vremenu u kome je emitovana“ (1973: 91). Upravo zbog mogućnosti različite interpretacije i manipulacije televizijskom slikom su velike. Informacija koju dobijamo iz slike u formi televizijskih vesti pod uticajem je pratećeg teksta. Slike potvrđuju tekst tako što stvaraju privid kao da nam daju istu poruku. Zato se smatra da značenje slike prizilazi iz konteksta i interpretacije što ga inicira govor, ali njeno prisustvo, vidljiv dokaz što ga pruža o događaju, dokazuje autentičnost prenosnika značenja teksta - 
„Odricati slici njeno svojstvo vizuelnog, to jest njeno svojstvo znaka da bismo je sveli na čisto vidljivo, neminovno znači i odricati joj svojstvo jezika“ (Žoli 2009: 113). Jezik slika pored svoje konkretnosti nije objektivni posrednik već deluje u određenom društvenom kontekstu, stimulišući određeno društveno ponašanje.

Za razliku od televizije štampa koristi prvenstveno diskurzivne simbole, odnosno prenosi pretežno faktografsko-logičke poruke (Miletić 1998: 62). Štampa je interpretativan medij, koji prilikom enkodiranja poruke, usled ograničenosti ikoničkih simbola, omogućuje vrednosno bojenje sadržaja, i s druge strane suženu mogućnost recepcijskih izbora u dekodiranju poruke, ističe Miletić. Jedna od osnovnih uloga fotografije u novinama jeste ,da privuče pažnju, konkretizuje tekstualnu informaciju i razbije prostornu monotoniju“ (Tošović 2002: 308). Zontag u svom delu o „O fotografiji“ (Zontag 2009) naglašava da su fotografije podjednako interpretacije (ili prezentacije) sveta koliko i naslikane slike i crteži. Bart je smatrao da je fotografija otvorena za mnoštvo različitih interpretacija jer nema kod, te je kod nje najvažnija njena dokazna snaga (Žoli 2009: 239). Da bi se novinska fotografija shvatila u svim svojim oblicima prvo se mora razumeti njen značaj, ali i njena ideološka uloga. „Fotografije su ključne za način na koji se vesti i gledišta predstavljaju javnosti. Što je još važnije, one su izgradile sopstveni vizuelni rečnik, fotografski jezik koji koristi čitav niz koncepata koji utiču na oblikovanje našeg razumevanja sveta“ (Holland 2005: 704). Fotografije danas mogu da budu često automatski simboličke. Njihova simbolička značenja delimično nastaju zato što već dajemo značenje stvarima u stvarnom svetu koje ona predstavaljaju, a delimično zato što fotografisanje nečega znači vršenje izbora u vezi sa značenjem. Na to vršenje izbora, kako Prajs tvrdi, delimično utiču predstave koje smo već videli. „Navikli smo da vidimo određenu vrstu ili tipove fotografija kojima pripisujemo značenje“"(Prajs 2011: 208).

\section{OZNAČAVANJE STVARNOSTI}

Kritički pristup koji razotkriva procese značenja i konstrukcije reprezentacije stvarnosti predstavlja semiologija. Lingvista Ferdinand de Sosir (1969) zamislio je semiologiju kao „nauku koja proučava život znakova u društvenom životu“. Istovremeno, američki filozof Čarls Sanders Pirs zamišlja jednu opštu teoriju znakova koju naziv semiotika. Za razliku od Sosira, koji je naglašavao društvenu funkciju 
znaka, Pirs je isticao njegovu logičku funkciju (Giro 1975). Kako smatra Giro, obe funkcije znaka usko su povezane i termini semiologija i semiotika pokrivaju jednu istu disciplinu. Pod „znakom“ se podrazumevaju i reči i slike i zvuci. „Znak uvek izražava nameru da saopšti jedan smisao“ (Giro1975 : 26). Znak sadrži označioca i označenog, a odnos između znakova predstavlja proces označavanja koji se odvija na denotativnom i konotativnom nivou (Bart 1971: 348). Drugi nivo je dvosmisleniji i otvoreniji za tumačenje: „Konotativno značenje je u osnovi kontekst ili pozadina koja u nekom smislu leži iza reči, slike ili predmeta. To je ono što mi unosimo, dodajemo ili podrazumevamo, a najmanje baš ono što je tu i što svi vide (Mek Kvin 2000 : 334)“. Konotacija, zapravo zajedno sa mitom, kao kulturološkom konstrukcijom, predstavlja drugi red označavanja. Neki znaci ili kombinacija znakova, mogu biti „zatvoreniji“ ili manje „polisemični“ (otvoreni za tumačenja) nego drugi. Otvoren tekst neće imati jasno određeno poželjno čitanje, a konotacije mogu biti dvosmislene i višeznačne. Bart ističe da je samoj prirodi vizuelnog svojstvena sposobnost prenošenja višestrukih kompleksnih značenja i to naziva „polisemijom slike“. On je pokazao „da je fotografija uvek otvorena za mnogo raznovrsnih interpretacija, delimično uslovljenih sadržajem slike, delimično njenim kontekstom, ali koja uvek crpi nešto od pretpostavki koje u nju unoste ‘čitaoci` (Barthes 1977 prema Holland 2005:708).“ Polisemija je, kako smatra Hol, nužnost svakog „televizijskog teksta“ budući da televizijska slika, kao i fotografija, za Barta naizgled nema kod na prvom nivou značenja, zbog čega tumačenje počiva na konotativnim kodovima. Složenost znakova i kodova pokazuju da je televizija visokopolisemičan medij, međutim, emisije vesti se u celini smatraju za visoko ,zatvorene tekstove“, jer tvorci programa uglavnom nameću poželjna značenja u odnosu na neka druga, i publici takva čitanja jasno sugerišu. Giro navodi da polisemiju znakova ne treba brkati sa polisemijom poruke. „Višesmislenost polisemičkog znaka ukinuta je kontekstom; u jednoj određenoj poruci, znak uglavnom ima samo jedan smisao. Ali može se desiti da to mnoštvo smislova bude sadržano u samo jednoj poruci“(Giro 1975: 33). Predstavnici socijalne semiotike zagovaraju tezu da su različite interpretacije, recepcije teksta bitne, kao i da su pretpostavke o njima utkane u sam proces konstruisanja poruke, te kao takve, i jedne i druge moraju biti predmet analize. Njihova glavna teza jeste da vuzuelna tj. semiotička sredstva doprinose stvaranju značenja isto toliko koliko i verbalna tj. lingvistička, kao i da se značenje stvara u njihovoj kombinaciji. Kako 
navodi Felbergova, osnovni princip ove teorije, čiji glavni predstavnici su Gunter Kres i Teo van Leven, inače pripadnici Halidijevske škole ${ }^{2}$, jeste da"multimodalni“"3 tekstovi kombinuju efekte različitih semiotičkih sistema i na taj način konstruišu značenje. „Različiti modaliteti, kao što su jezik i fotografija imaju različite organizacione principe za stvaranje značenja na osnovu svojih funkcija.Međutim, verbalni i vizuluelni tekstovi koriste svoje sisteme mogućih formi i kombinacija i stvaraju značenje koje se tumači u okviru konteksta u kojem se stvaraju“ (Radanović Felberg 2010: 284). Prema Eku, kontekst predstavlja „svet kulturnih konvencija sa značenjem neizbrisive stvarnosti; on vezuje komunikaciju i poruku za kontekst svakodnevnog života“ (Eko: 1973). Dakle, kontekst menja smisao, funkciju i informativnu kvotu poruke.

\section{SIROMAŠTVO I SOCIJALNO ISKLJUČENE GRUPE U SRBIJI}

U savremenim uslovima termin siromaštva se sve teže precizno definiše zbog njegovog multidimenzionalnog karaktera. U sociološkim studijama se uglavnom ističe da se ono manifestuje na razne načine, kao što su: ,nedostatak prihoda i sredstava dovoljnih da se osigura održiva egzistencija; glad i neuhranjenost; slabo zdravlje; ograničena ili nikakva dostupnost obrazovanju i ostalim temeljnim uslugama; povećana smrtnost; uključujući smrtnost od bolesti; beskućništvo i neadekvatni stambeni uslovi; nesigurno okruženje, društvena diskriminacija i izolacija“" (Tomić 2007: 149). Siromaštvo se shvata kao apsolutna ili relativna kategorija, ${ }^{4}$ a pri određivanju ko su siromašni upotrebljavaju se objektivna ili subjektivna merila. U zavisnosti od toga za koju kategoriju tumačenja siromaštva se u zvaničnim statistikama vlade pojedinih država odluče, prikazane brojke se razlikuju. U Srbiji se govori samo o onima koji žive ispod granice apsolutnog siromaštva. Usvajanjem Strategije za smanjenje siromaštva 2003. godine postavljen je okvir kako da se na nacionalnom i lokalnom nivou razvijaju i sprovode mere koje bi trebalo da doprinesu smanjenju apsolutnog siromaštva građana Srbije. Upravo u tom dokumentu ističe se

2 Halidej (Halliday Hasan) je predstavnik funkcionalne lingvistike

3 Verbalni i vizuelni elementi koji čine različite semiotičke sisteme nazivaju se modaliteti (modalities); te stoga i multimodalni (Felberg 2010).

4 Koncept apsolutnog siromaštva - podrazumeva osnovne uslove koje treba ispuniti kako bi se održala fizički zdrava egzistencija, dok koncept relativnog siromaštva - siromaštvo određuje u odnosima na ukupni standard koji preovlada u određenom društvu. 
da značajnu ulogu u borbi protiv ove pošasti osim države trebaju da imaju i mediji, a posredno i pojedinac, ,kroz sticanje znanja o svim oblicima siromaštva i socijalnog isključivanja, razlozima koji do njih dovode, ali i načina za njihovo iskorenjivanje. “5 To bi na širem planu, kako se navodi u strategiji, vodilo povećanju svesti. Skoro deceniju kasnije, broj siromašnih građana Srbije, prema poslednjim procenama Ministarstva rada i socijalne politike i dalje ima uzlaznu putanju. U 2010. u odnosu na 2009. godinu broj siromašnih porastao je za 2,3 procentna poena (sa $6,9 \%$ na $9,2 \%$ ) i trenutno više od 700.000 ljudi živi ispod granice siromaštva. Među socijalno najugroženije grupe spadaju: deca, mladi, osobe sa invaliditetom, izbegla i interno raseljena lica, Romi, ruralno siromašno stanovništvo i neobrazovani. Istraživanje koje naučni tim Odseka za medijske studije Filozofskog fakulteta u Novom Sadu sprovodi od 2010. godine u okviru projekta „Medijski diskurs o siromaštvu i socijalnoj isključenosti“" ${ }^{\text {"6 }}$ pokazaje da ova problematika, nažalost, nije visoko na dnevnom redu masovnih medija u Srbiji. Izveštava se površno kroz faktografske žanrove o krajnjim posledicima određenih događaja, ne ulazeći toliko u razloge (uzroke) siromaštva. Nudi se jednodimenzionalna slika fokusirana na opšte siromaštvo. Najsiromašniji se prikazuju putem bezličnog pristupa u brojkama (statistički podaci) i kao anonimni građani (vox populi), a u njihovo ime uglavnom govore vladajuće strukture.

\section{CILJEVI I METODOLOGIJA ISTRAŽIVANJA}

Polazeći od navedenih rezultata, osnovni cilj istraživanja ovog rada bio je da se u posmatranim tekstovima utvrdi i na koji način se vizuelno predstavljaju različite dimenzije siromaštva injihovi glavni akteri. Posmatrajući da li i u kojoj meri televizijske slike i fotografije objavljene u dnevnoj štampi i veb portalima potvrđuju verbalne komentare posmatranih tekstova, cilj je bio i da se prikaže na koji način semiotička sredstva doprinose konstrukciji i učvršćivanju određenih značenja krajnjih poruka. U istraživanju je primenjen metod kvantitativno-kvalitativne analize sadržaje. Budući da analiza sadržaja ne sadrži teorijski okvir kojim bi se objasnili značenjski procesi, u radu su primenjene i određene semiotičke metode. Kao prvi korak analize napravljen je kodni list, sa posebnim kategorijama kako bi se uvažile specifičnosti posmatranih

$5 \quad$ Strategija za smanjenje siromaštva u Srbiji, www.inkluzija.gov.rs

6 Videti zbornik radova"Media, Poverty and Social Exclusion" (2011), Novi Sad: Filozofski fakultet u Novom Sadu 
medija. Osnovne kategorije o vrstama socijalne isključenosti i socijalno isključenim grupama $^{7}$ kreirane su prema sistemu klasifikovanja podataka o siromašnima u Srbiji. Uzorak su činili tekstovi o siromaštvu koji su prikupljeni u periodu od 14. do 28. oktobra 2010. godine i 2011. godine. Prve godine praćeno je po sedam centralnih informativnih emisija koje su emitovane na sedam televizijskih stanica i po sedam izdanja pet dnevnih novina, kao i po dva izdanja nedeljnih novina. Druge godine je uzorak smanjen na četiri televizijske stanice i četvore dnevne novine, a uključeno je sedmodnevno praćenje postavljenih vesti na veb portalima. Kriterijumi za odabir medija bili su: teritorijalna pokrivenosti (nacionalni, regionalni i lokalni mediji), vlasnička struktura i model organizovanja (profitno-komercijalni mediji i javni RTV servisi), način tretiranja sadržaja u štampi (tabloidna i ozbiljna štampa) i posećenost veb portala. Analizirani medijski tekstovi emitovani su ili objavljeni u sledećim medijima - Televizija: Radio-televizija Srbije, Radio-televizija Vojvodine, TV B92, TV Prva, YU ECO, TV Pirot i TV5 (2011. su izostavljeni: TV Prva, YU ECO i TV pirot); Štampa: Politika, Dnevnik, Blic, Press, Narodne novine, Novine vranjske i Kikindske novine (2011. su izostavljeni: Press, Kikindske novine, Blic); Veb portali: www.b92. net $i$ www.bliconline.rs. Na osnovu već prethodno pomenutog definisanog okvira analitičkih varijabli sadržaja, izdvojeno je 410 tekstova o siromaštvu ( televizija 112, štampa - 231 i internet - 121) kao mogući uzorak za dalju analizu diskursa.

Da bi se shvatila poruka koju televizijske slike i fotografije konstruišu, neophodno je razumeti kodove koji su pri tom upotrebljeni, a koji prozilaze iz sistema vrednosti i znanja koji dele proizvođači i recipijenti poruke. Bart je svojevremeno zaključio da televizija potvrđuje da je sve znak (1979:465-477), s obzirom da proizvodi značenja vizuelno i verbalno, korišćenjem velikog broja znakova kombinovanih u složene konvencije i kodove (slikovne, zvukovne i prirodnojezičke). Osnovna foma svojstvena vizuelnom mediju je tipično ikonički način organizovanja podataka, dok simboli imaju denotativno značenje (u tumačenju audio sadržaja televizijske slike), ali i konotativno, koje se uglavnom odnosi na televizijsku interpunkciju (plan kadra, rakurs snimanja, specijalne efekte). Kao što je već ranije naglašeno u radu, slika se u televizijskim vestima ne može odvojeno posmatrati od verbalnog komentara koji

7 1.Siromašni radnici:žrtve privatizacije, zaposleni u štrajku, ostali radnici. 2. Socijalno isključene grupe: žene, deca, mladi, studenti, stari, penzioneri, beskućnici, izbegla i raseljena lica, osobe sa invaliditetom, etničke manjine(Romi itd.) stanovnici prigradskih naselja, svi siromašni građani Srbije, gladni, korisnici narodnih kuhinje. 
je prati i obrnuto, bez obzira na to što su teoretičari utvrdili da su diskursi slike i tonskog zapisa, osim retkih izuzetaka, uglavnom međusobno nepovezani. „Šizofrena nepovezanost ova dva diskursa više vodi ka popuštanju pažnje nego ka traženju primene pravila filmskog čitanja koje povezuje diskurs slike i diskurs zvuka" (Žoli 2009: 212). Upravo zbog tog krhke veze slike i teksta, što navodi pažljivog gledaoca da prati samo jedan od ova dva istovremena diskursa, polazište za analizu slike u ovom radu bila su pitanja preuzeta iz ranijih istraživanja (Drašković 2010): Da li slika pruža dokaz koji podržava ono što je rečeno u tekstu? Koliko nam omogućava da „sami vidimo“? Koji je dublji smisao i kakve su posledice te namene slike? Da li je dokumentaristički ili asocijativan prikaz? Koji su najčešće korišćeni planovi ${ }^{8} \mathrm{u}$ proizvodnji televizijskih vesti, odnosno razdaljina kamere od objekta posmatranja, ugla posmatranja i njihovog značenja?

Bart je identifikovao neke od kodova koji učestvuju u konstruisanju značenja novinske fotografije. Početak njihovog delovanja je kada dekodiranje značenja koje vrši pažljivi čitalac postaje svesno i analitično umesto samo intuitivno (1977:21). Slično tome, Stjuart Hol izveo je detaljnu analizu procesa u kome novinske fotografije najpre kodiraju oni koji ih proizvode, a zatim ih dekodiraju njihovi čitaoci, ističući načine na koje kontekst slike utiče na njenu interpretaciju (Hall 1973: 176). Hol je (1981) ustanovio i osam nivoa prilikom odlučivanja o izboru fotografija uz vest: tehnički, formalni, kompozicija, ekspresija, informativna vrednost, manipulacija kadrom, integracija sa stranicom i fiksiranje. Čitav aparat proizvodnje vesti počinje da deluje na petom nivou, nivou informativne vrednosti koji predstavlja nivo slelekcije, jer publika podrazumeva da se ljudi ili okruženje pri izboru rukovode već postojećim značenjima; ona su kodirana i poznata na osnovu prethodnog materijala, pa postaje ograničen okvir mogućih značenja koja bi mogla da imaju (Hol 1981 prema Prajs 2010: 339). Predstavnici socijalne semiotike Kres i Van Levena u analizama novinskih fotografija kao važne elemente izdvajaju: ,a) kontakt (contact), tj. da li nam učesnici na fotografijama nude određenu informaciju i nešto od nas zahtevaju; b) društvenu razdaljinu (social distance), tj. razmak između učesnika u komunijaciji, koji može biti intiman, društven ili ne-ličan i c) modalnost (modality) tj. pitanje istine koje se na fotografijama izražava kroz naturalističku ili apstraktnu orjentaciju koja se postiže kroz izbor boje, dubine, iluminaciju itd. (Radanović Felberg 2010: 285).

8 Plan je veličina objekta snimanja, najčešće čovekove figure u okviru filmskog kadra (Leksikon filmskih i televizijskih pojmova) 


\section{ANALIZA}

Analiza se sastoji iz dva dela (analiza televizijske slike i analiza fotografija) i fokusirana je na predstavljanje najzastupljenijih kategorisanih aktera siromaštva u posmatranim tekstovima:siromašni radnici (zaposleni u štrajku), penzioneri, nezaposleni, studenti i svi siromašni građani Srbije. Posmatranjem 112 televizijskih vesti o siromaštvu potvrđene su ranije kvalifikacije o labavoj i posrednoj vezi između teksta i slike. Tek u polovini (51\%) analiziranih vesti iz 2010.godine ili nešto malo više (65\%) iz 2011. godine slika pruža dokaz koji podražava ono šta je rečeno u tekstu (,u ofu“). U 76\% priloga od druge polovine koja ne podržava slika govori manje u odnosu na verbalni komentar, u 21 odsto slučajeva slika banalno ilustruje vesti, dok su ostale neodređene. Vizuelna ilustracija informacija o opštem ekonomskom siromaštvu (svi siromašni građani Srbije), u gotovo u svim televizijskim dnevnicima svodi se repeticiju „praznih kadrova“ u kojima slučajni prolaznici šetaju ulicama grada ili kupuju u prodavnicama. Slike se, dakle, koriste kao nužno zlo za ilustraciju i u tim slučajevima nemaju snagu uverljivosti jer bezličan pristup ne može da razvije neki vid empatije prema temi siromaštva. S druge strane najsiromašniji slojevi stanovništva više se predstavljaju uglavnom kroz krupne kadrove neuglednih korisnika narodnih kuhinja (slika 1), kako bi se potvrdile već usvojene predstave gledalaca o ovim socijalnim grupama. Kadar se, u televizijskim vestima, koristi prema utvrđenim principima za ostvarivanje planiranih efekata na definisanu ciljnu publiku. Najčešće korišćen je krupni plan zbog svoje ekspresivnosti. Televizijske poruke su, kako ističe Babac, više lične i stalno nam nešto govore o ekpresivnosti onoga ko nam je prenosi, o tome kako se oseća i kako emocionalno reaguje (2000). S druge strane, krupni plan ne prikazuje čitav događaj, otkrivena je samo jedna strana realnosti, dok se druga strana filtrira, ona je ignorisana, nevidljiva i nečujna. Ali, ta jedna, polovično vidjiva i čujna, strana realnosti za gledaoce je sasvim uverljiva i u psihološkom smislu predstavlja punu realnost, smatra Babac. Tako svedeno predstavljanje na male delove slika, koje je evidentno i u posmatranom uzorku, govori da se masovna publika izlaže vrlo maloj dozi „pretećih faktora“, kako bi zapravo društvo očvrsnulo u odolevanju tim uticajima. Zato se i štrajkovi sindikalaca ili studenata (u slučaju uličnih protesta) prikazuju u prvom planu kroz najupečatljivije transparente (slika 2). Penzioneri, kao jedna od najvidljivijih siromašnih grupa u medijima, su "čekači“ koji ništa drugo ne 
rade osim što stoje u redovima ispred zgrade pošte ili banake i čekaju penzije (slika 3). Ovakva predstava upućuje na to da su penzioneri na teretu društva u kontekstu ekonomskih prilika

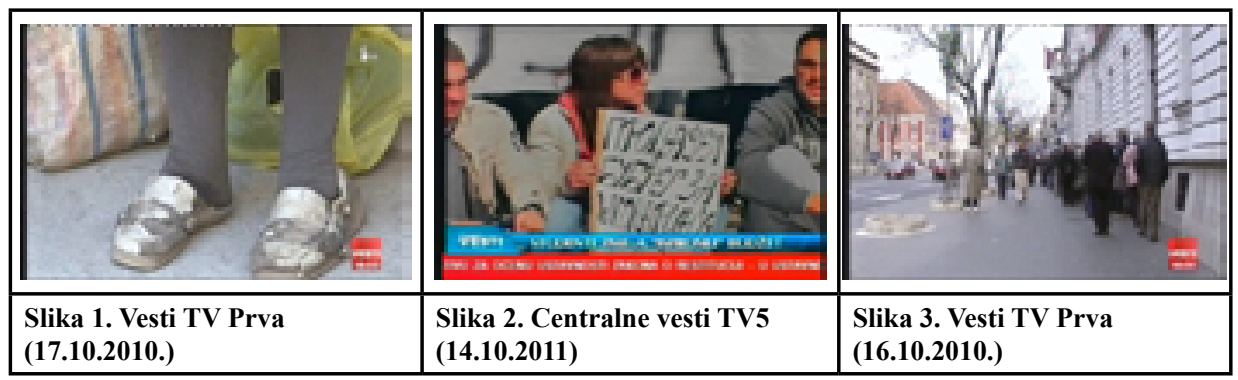

u zemlji. U posmatranom korpusu utvrđeno je i da se siromaštvo u televizijskoj slici često vizuleno predstavlja i kroz stereotip pedagoškog obrasca (slike 4 i 5). Stalno ponavljanje ovog obrasca sa širokim spektrom brojeva, tabela, strelica, procenata podrazumeva, kako primećuje teoretičarka Žoli, već utvrđeni stereotip „da specijalisti znaju, a gledalac ne“ (2010: 202).

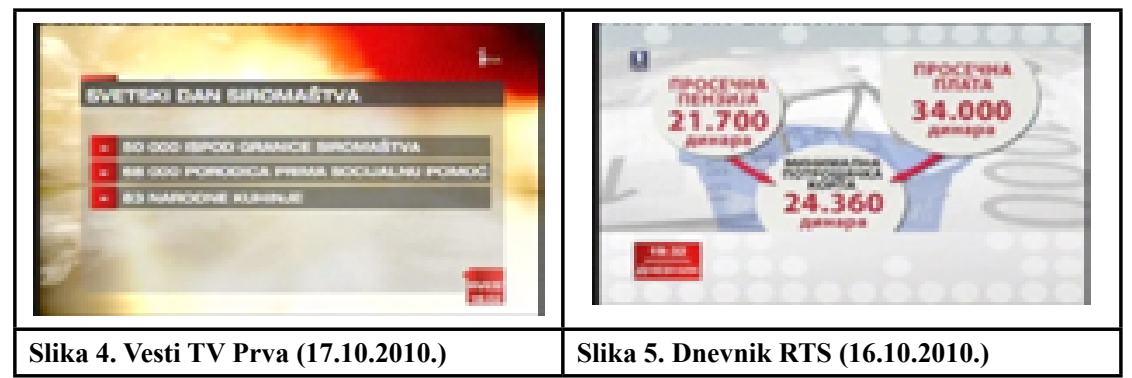

Sugestivna snaga grafičkih ilustracija, pogotovo simbola i metafora može da bude veoma velika. Bojd (2002: 207) ukazuje na to da televizijske grafike mogu mnogo dopuniti izlaganje činjenica i objasniti kontekst neke priče tako što se na ekranu pojavljuju ključni podaci i citati iz teksta. Ali, s druge strane postavlja se pitanje koliko zaista taj stereotipni pedagoški pristup može da proizvede kod gledaoca očekivani efekat. „Njegov sadržaj je sveden i suviše brzo prikazan da bi mogao da pruži bilo kakvu poduku“ (Žoli 2009: 202).

Kao što je slučaj kod televizijske slike, i u analizi fotografija u posmatranom 
uzorku $u^{9}$ potvrđena je primena strategije stereotipnog prikazivanja glavnih aktera siromaštva. U svim novinama koje su prenele vest o protestu sindikalaca primećene su fotografije koje na sličan način ilustruju ovu vrstu događaja i putem kojih se najlakše i najbolje prepoznaju ove društvene grupe: sa transparentima i zastavama u rukama (slika 8) kojima na simboličan način izražavaju bunt. Urednički izbor da informaciju o protestu sindikalaca ilustruje fotografijom na kojoj je jedan od članova omotan jugoslovenskom zastavom (slika 7) nudi polisemnu poruku. Na prvom nivou upućuje na nostalgičan odnos za nekadašnjom socijalističkom državom u kojoj se živelo sigurnije, solidarnije, stabilnije, dok na dubljem nivou značenja može da sugeriše i negativne ideološke implikacije u zavisnosti od toga ko je „čita“. Fotografija radnika koji stoji na šinama sa direktnom porukom upućenom poslodavcu (slika 6) ukazuje na intimnu distancu učesnika u komunikaciji. Direktan pogled radnika u

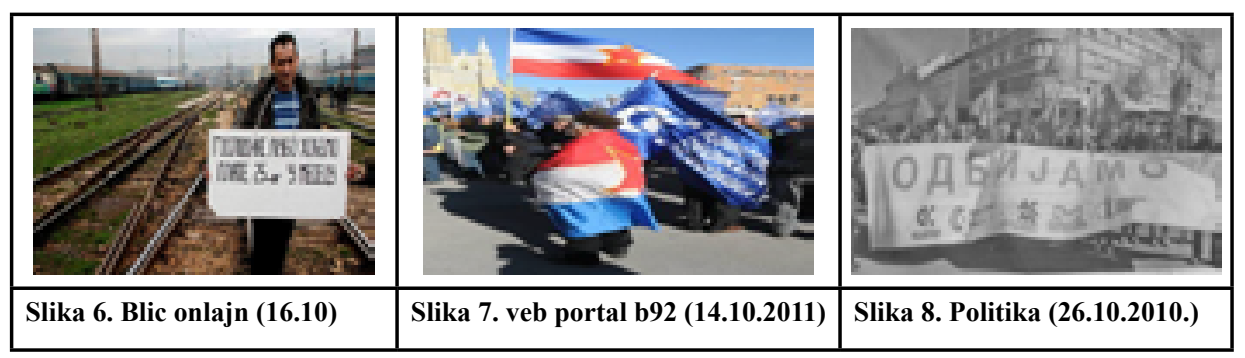

posmatračeve oči može se tumačiti kao govorni čin „potražnje“ (prema Halidijevoj podeli govornih činova), a kontekst u koji je smeštena produbljuje značenje na denotativnom novou i sugeriše da su svi vozovi već odavno prošli za drugačiji vid rešavanja problema. Osim dokumentarističkog svojstva koji potvrđuje verodostojnost da su načinjene na licu mesta, značenje ovih fotografija može da se tumači i sa ideološkog stanovišta budući da ova vrsta prikazivanja siromašnih radnika i sindikalaca prenosi određenu vrednost.,,Ideološke implikacije stereotipa su očigledne, pošto su grupe koje su najviše podložne stereotipima one sa manje društvene i kulturne moći“ (Medherst 2005: 480).

Kao i slučaju u TV slike penzioneri na fotografijama se na denotativnom nivou predstavljaju kao estetski neugledni: tromog hoda dok šetaju ili povijenog

$9 \quad$ Kodiranjem je utvrđeno da je $76 \%$ tekstova u prvom (2010.), a 71\% u drugom (2011.)uzorku ima vizuelnu prezentaciju. 
tela dok stoje u redovima. Fotografija uz analitički tekst o neodrživosti i rizičnosti penzionog sistema u Srbiji naslovljen „U Srbiji ima gotovo isto radnika i penzionera“ (slika 9) predstavlja dobar primer kodnog preplitanja - ,ukrštanja prirodnog jezičkog koda i neverbalnog koda tj. vanjezičkog sistema znakova“ (Tošović 2002: 247), međutim, s druge strane, pruža stereotipnu predstavu koja ukazuje na to da svi penzioneri izgledaju nemoćno i skrušeno poput starice koja je u krupnom planu na slici. I dok je u novinama svaki tekst ilustrovan zasebnom fotografijom, na veb portalu www.b92.net uočeno je da se pribegava rabljenju jedne iste fotografije za ilustraciju različitih tekstova, što je manipulativan urednički čin. Fotografija starijeg muškarca u krupnom planu koji se čvrsto drži za rešetke ograde sa pogledom usmerenim van fokusa objektiva (slika 11) iskorišćena za ilustraciju dva teksta, ${ }^{10} \mathrm{dok}$ fotografija sa grupom starijih osoba okrenutih leđima u redu za namirnice ilustruje (slika 10) tri različita teksta o penzionerima. ${ }^{11}$ Reč je o fotografijama koje nam ne daju verodostojnu informaciju.

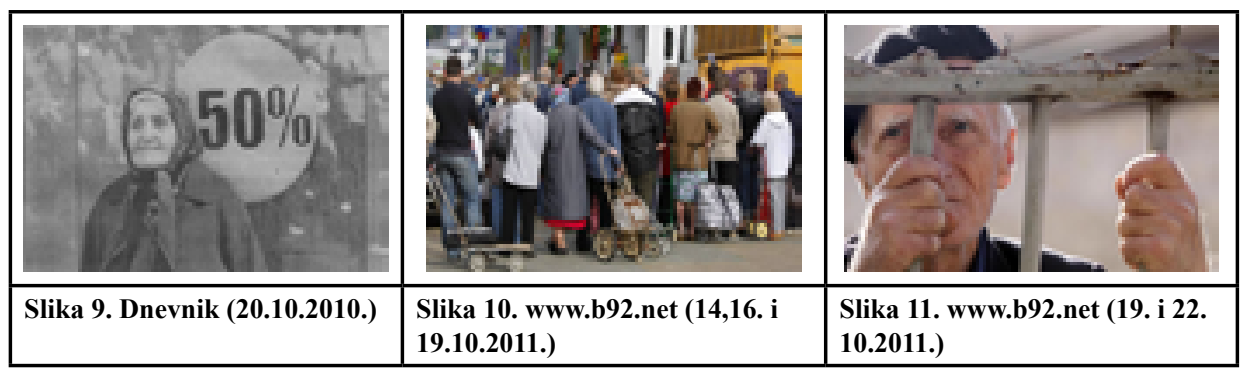

Figure su predstavljene u pozama koje denotiraju očekivanu statičnost $\mathrm{i}$ marginalizaciju ovih aktera u društvu. Budući da je sam okvir medijskih priča u našem uzorku fokusiran na opšte siromaštvo, a ne na epizodne priče, odnosno human interest pristup, sasvim je očekivano da su urednici svesno odabrali fotografije koje nemaju informativnu vrednost već se očekuje da na asocijativnom nivou komuniciraju sa čitaocem. Glavna scenografija u kojoj se najsiromašniji akteri predstavljaju su kontejneri za smeće (slike 12, 13. i 14.). Pozicija predstavljenih učesnika je skrajnuta u desni ugao. Lica (samo se jedno vidi) ne gledaju u posmatrača što kontakt svodi na

10 „Za pola godine neće biti penzija“ (19.10.), „Penzije rastu za čak 1,5 eura“ (22.10.)

11 „Pola penzija plaćaju iz našeg džepa“ (14.10), „Isplata penzija“ (16.10) „Previše penzionera u Srbiji“ (19.10.) 
distancu. Gornji rakurs iz kojeg je fotografisana osoba sa jednom rukom u kontejneru (slika 13), a drugom se oslanja na štap dodatno pojačava sva ona značenja

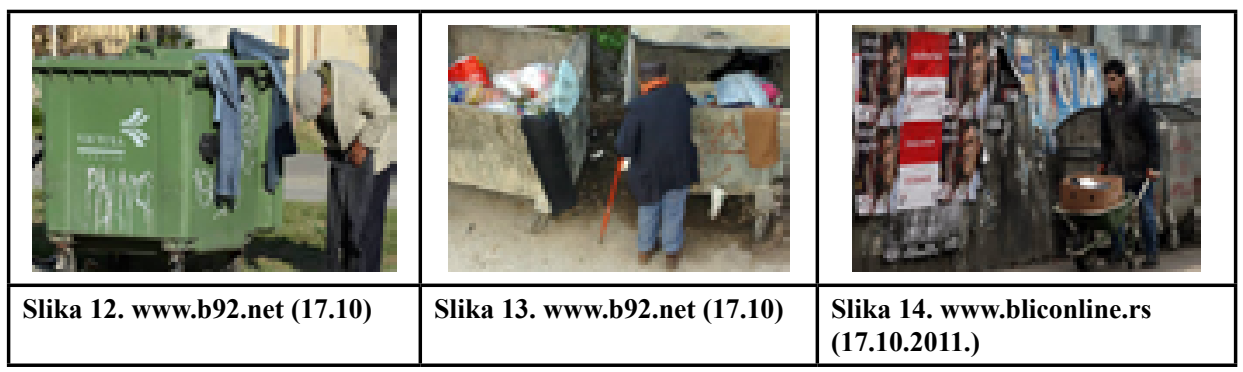

koja se pripisuju marginalnoj društvenoj grupi kojoj pripada. Fotografija na kojoj mladić gura kolica ima dodatnu konotaciju - ideološku pozadinu jer je stavljena u direktan politički kontekst (naslov teksta: „Oko 45 odsto stanovnika Kosova živi ispod granice stanovništva“), dok značenje treće fotografije u kojoj osoba odmerava koje mu farmerke pašu upućuje na ironični diskurs u odnosu na verbalni komentar (naslov teksta: „Siromaštvo se meri sa 8.500 hiljada dinara“). Sve tri fotografije su upotrebljene za ilustraciju tekstova u kojima se iznose statistički podaci povodom Svetskog dana borbe protiv siromaštva sa već svesnom namerom da se konotacije izgrađuju na već postojećim predstavama o siromašnim.

\section{ZAKLJUČNE NAPOMENE}

Rezultati analize pokazaju da se televizijski kadrovi i fotografije $u$ posmatranim tekstovima uglavnom koriste kao nužno zlo za ilustraciju različitih dimenzija siromaštva i njegovih glavnih aktera, te da u tim slučajevima uglavnom nemaju snagu uverljivosti. Većina fotografija nema informativnu vrednost već na asocijativnom nivou proizvodi značenja. Dominiraju dva tip fotografija na kojima se akteri pojavljuju kao ranjivi pojedinci ili kao nevidljiva grupa. Pozicija predstavljenih učesnika varira, a većina ne gleda direktno u posmatrače, što odgovara govornom činu ponude. U relaciji sa drugim učesnicima, ako ih ima na fotografijama, denotiraju očekivanu statičnost i simboličku marginalizaciju ovih aktera u društvu. Ispitivanje strukture diskursa, dakle, pokazuje da je vizuelno predstavljanje glavnih aktera siromaštva pojednostavljeno, stereotipno i daleko od prikazivanja celokupnog 
konteksta. Svedeno je na male delove slika, koji nemaju tu snagu da dočaraju na pravi način ozbiljnu problematiku siromaštva i sa kojim se masovna publika teško identifikuje. Tendenciozno nametanje značenja poruka onima koji ih dekodiraju odražava trend „vakcinacije“ kojim se masovna publika izlaže vrlo maloj dozi „pretećih agenasa“ da bi društvo očvrsnulo u odolevanju tim uticajima. Osećaj da celo društvo tone izaziva pomirljivost što odgovara najpre političkim elitama koje, kako je već dokazano, putem medija nameću svoje konstrukcije stvarnosti.

\section{LITERATURA}

Babac, M. (2000). Jezik montaže pokretnih slika. Beograd: Clio.

Bart, Rolan (1971). Književnost, mitologija, semiologija. Beograd: Nolit.

Bart, Rolan (1979). Retorika slike. Treći program Radio Beograda 41. (465477).

Bojd, Endriju (2002). Novinarstvo u elektronskim medijima. Beograd: Clio.

Drašković, B. 2010. Funkcija slike u ilustraciji televizijskih priloga. CM: Časopis za upravljanje komuniciranjem, V (14), 61-81.

Eko, Umberto (1973). Kultura Informacija Komunikacija, Beograd : Nolit

Giro, Pjer (1975). Semiologija. Beograd : Beogradski izdavačko - grafički zavod.

Hall, Stuart (1982). The rediscovery of ideology: the return of the repressed in media studies. In Gurevitch, M. et al. (eds.). Culture, society and the media. London: Methuen, 56-90.

Holand, Patriša (2005). „Direktno obraćanje oku“? Fotografija i štampa. U Brigs, A. i P. Kobli (prir.). Uvod u studije medija. Beograd: Clio

Kleut J., Drašković B., Prodanović D.(2011). Stereotipi o siromašnima u srpskim medijima, izlaganje na konferenciji „Nauka i savremeni univerzitet“, 10. novembar 2011, Niš, Srbija.

Mek Kvin, Dejvid (2000). Televizija. Beograd: Clio.

Medherts, Endi (2005). Seksualnost: Prizori želje: seksualnost u medijskim tekstovima. U Brigs, A. i P. Kobli (prir.). Uvod u studije medija. Beograd: Clio

Miletić, Mirko(1998).Komuniciranje u novm medijskim uslovima.Jagodina: Učiteljski fakultet

Prajs, Stjuart (2011). Izučavanje medija. Beograd: Clio 
Radanović Felberg, Tatjana(2010). Socio-semiotička konstrukcija Mila Đukanovića i Slobodana Miloševića na naslovnim stranicama Politike i Pobjede u toku NATO bombardovanja 1999.godine.U Vasić, Vera (ur). Diskurs $i$ diskursi.Novi Sad: Filozofski fakultet u Novom Sadu, 283-299.

Strategija za smanjenje siromaštva u Srbiji (2003). URL:http://www. inkluzija.gov.rs

Tomić, Velinka (2007). Siromaštvo i socijalna isključenost - osnovne definicije i indikatori, Sociološka luča, 1/2, str, 149-166. Posećeno 10.09.2010.

Tošović, Branko (2002). Funkcionalni stilovi. Beograd: Beogradska knjiga

Zontag, Suzan (2009). O fotografiji. Beograd: KCB (Kulturni centar Beograd)

Žoli, Martina (2009), Slika i njeno tumačenje. Beograd: Clio.

Brankica Drašković

\section{VISUAL REPRESENTATION OF MAIN ACTORS OF POVERTY IN SERBIA: SEMIOTIC ANALYSIS OF TELEVISION IMAGE AND PHOTOGRAPHY IN MEDIA TEXTS}

\section{Summary}

This paper analyzes the media's visual representation of various poverty groups within Serbia.The visual representation is not simply a reflection of reality, but rather an instrument that plays an important role in prescribing different meaning to media events and their appearances in public.The aim of this research is to determine how the visual code transmits messages about poverty and socially excluded groups, in the analyzed television news, newspaper and online photographs. Based on the sample of 410 articles on poverty, collected between the 14th and 28th of October 2010 and 2011, this paper critically analyses the medias representation of poverty within Serbian society through methods of content analysis, critical discourse studies, and the use of semiotic approahes to images.

Analysis of the structure of discourse shows that the visual representation of the poor in Serbian society is highly simplified, stereotyped and is seperated from the wider societal context of poverty. It is rather reduced to bits and pieces of media images, which do not properly indicate the seriousnes of the problem of poverty making it difficult for mass audiences to identify with. 
Key words: poverty ,visual presenations, television news, television image, discourse analysis, photography, social semiotics 